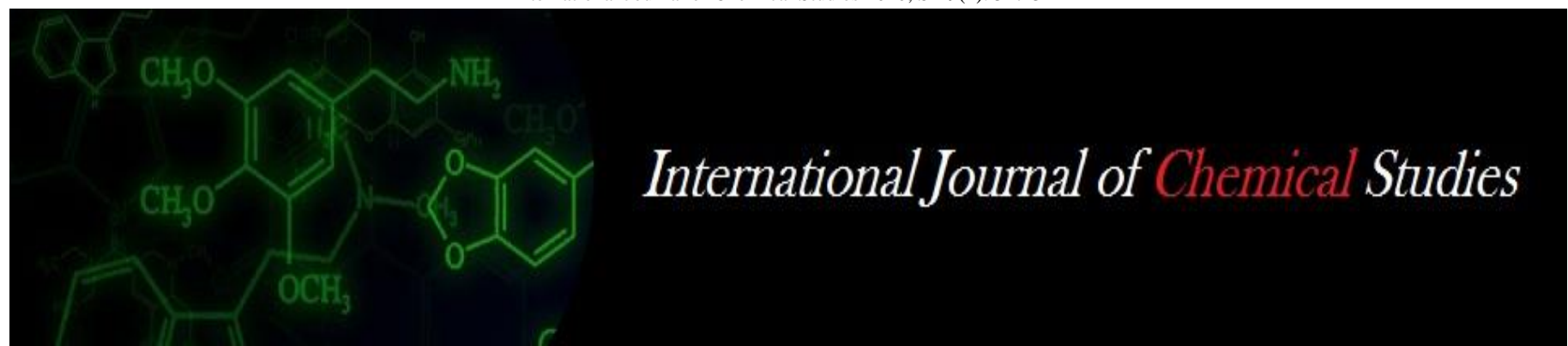

P-ISSN: 2349-8528

E-ISSN: 2321-4902

www.chemijournal.com

IJCS 2021; SP-9(1): 317-322

(C) 2021 IJCS

Received: 19-10-2020

Accepted: 29-11-2020

Mridu Megha Dalai

M.Tech, Department of

Agricultural Processing and

Food Engineering, College of

Agricultural Engineering and

Technology, OUAT,

Bhubaneswar, Odisha, India

Manoj Kumar Panda

Professor and Research

Engineer, AICRP on PHET,

Department of Agricultural

Processing and Food

Engineering, College of

Agricultural Engineering and

Technology, OUAT,

Bhubaneswar, Odisha, India

Corresponding Author:

Mridu Megha Dalai

M.Tech, Department of

Agricultural Processing and

Food Engineering, College of

Agricultural Engineering and

Technology, OUAT,

Bhubaneswar, Odisha, India

\section{Studies on preservation of sugarcane juice using hurdle technology}

\author{
Mridu Megha Dalai and Manoj Kumar Panda
}

DOI: https://doi.org/10.22271/chemi.2021.v9.i1f.11781

\begin{abstract}
Hurdle technology is an emerging concept in which a particular hurdle or an obstacle is provided to the food product in order to prevent or slow down the growth of enzymes by ensuring its quality and safety. One such hurdle used in here is pasteurization treatment at high temperature and for less holding time. Pasteurization treatment at high temperature and for less holding time was found to be an effective method to reduce the microbial load and PPO activity and hence preserve the color and flavor of sugarcane juice. A study was conducted to observe the effect of pasteurization treatment at different temperature $\left(80,90,100{ }^{\circ} \mathrm{C}\right)$ and holding time $(60,90,120 \mathrm{sec})$ to enhance the shelf life of juice. Among different tests, it was observed that pasteurization treatment at $90{ }^{\circ} \mathrm{C}$ for holding time $90 \mathrm{sec}$ was found to produce the best quality with reference to different quality attributes. In general, the combination was selected as it showed maximum decrease in reducing sugar, PPO activity and higher sensory scores. Therefore pasteurization at $90{ }^{\circ} \mathrm{C}$ for $90 \mathrm{sec}$ found to be an optimum treatment for preservation of sugarcane juice.
\end{abstract}

Keywords: Sugarcane juice, hurdle technology, pasteurization treatment, color, TSS, reducing sugar, polyphenol oxidase activity, microbial load, storage

\section{Introduction}

Sugarcane (Saccharum offcinarum) is a cash crop belongs to the family of grass Poaceae. In India it is cultivated mainly for sugar and juice (direct consumption). It is our pride that India became the largest sugar producing country in 2018-19 beating out Brazil for the first time in 16 years and produced about 33 million metric tonne of sugar. Cane juice is one of the energy booster, full of carbohydrates and iron, medically juice is useful for the treatment of enlarged prostate, reduce acidity, ailments like cystites, nephritis and gonorrhea. As it is alkaline in nature and due to the high concentration of magnesium, iron, potassium, and calcium, it prevents cancer. Its regular use can help to gain weight to under nutrition person (Kalpana et al., 2013) ${ }^{[4]}$. Sugarcane juice after extraction cannot be stored on more than 24 hours with its original taste and aroma even in a chilled condition that is the reason why we see expellers everywhere all the year. The problem associated with it is after extraction it get spoiled due to the fast fermentation as it contains about $0.5 \%$ reducing sugar, $15-18 \%$ sucrose, mineral salts and adequate amount of organic nitrogen for microbial growth (Qudsieh et al., 2002) ${ }^{[8]}$. pH more than 4.6 makes it favourable for growth of pathogens. Major factor contributing quality loss in food and beverages is enzymatic browning which changes the color of the beverage due to presence of polyphenol oxidase enzyme (PPO). Contamination of juice is also the main reason of its spoilage, due to the environment in which it is prepared resulting rapid damage to taste, color and flavor. Hurdle Technology happens to be a new and efficient concept and technique for improving the quality of food and to enhance its shelf life. Basically the hurdle is a kind of barrier or an obstacle provided to a food product in order to prevent or slow down the growth of enzymes. The implementation of any kind of hurdle is to be done in such a way that it does affect the quality and originality of the food. Once the factors responsible to damage the sugarcane juice are defeated or killed permanently, evolution world wild in cold drinks sector would be achieved. 


\section{Materials and Methods}

Preparation of Sugarcane Juice

The study was conducted at "College of Agricultural Engineering and Technology" and the raw materials were procured from the farm field itself.

The sugarcanes were peeled by eliminating the joints to reduce the microbial load which can be present at surface and joints.

Thereafter canes and extractor both were cleaned with KMS (potassium metabisulphite) with water before extraction of juice.
Then fresh sugarcane juice was extracted and was filtered by using muslin fabric cloth.

\section{Application of Pasteurization Treatment}

The oven was used to pasteurize the fresh cane juice extracted after standardization to $\mathrm{pH} 4.6$ and TSS $14{ }^{\circ} \mathrm{Brix}$. It was pasteurized at temperature $80,90,100^{\circ} \mathrm{C}$ for $60,90,120$ seconds. After the treatment given the samples were taken out cooled and filtered as sediments were deposited on the top of the juice. The treated juice was thereafter filled in sterilized glass bottles.

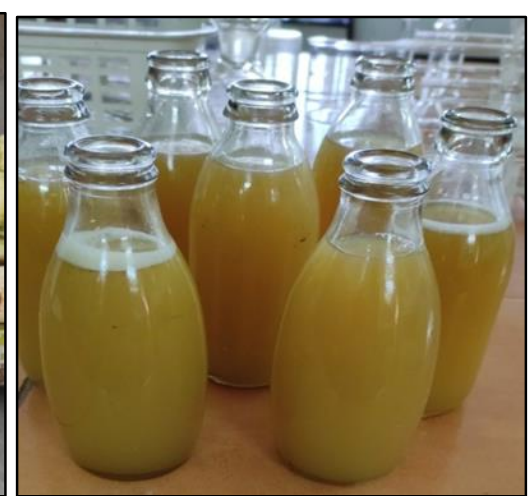

Fig 2: Pasteurized sugarcane juice

Fig 1: Peeled Sugarcanes

Table 1: Study parameters

\begin{tabular}{|c|c|}
\hline Independent variables & Dependent variables \\
\hline Fixed parameters & $\begin{array}{c}\text { After extraction, juice was standardized to } \\
\text { a certain TSS, pH i.e. } \\
\text { TSS }\left(14^{0} \mathrm{Brix}\right), \mathrm{pH}(4.6)\end{array}$ \\
\hline & Colour \\
TSS \\
Pasteurisation- & Titrable acidity \\
Memperature $\left({ }^{\circ} \mathrm{C}\right)-80,90,100$ & Microbial load \\
Holding time $(\mathrm{sec})-60,90,120$. & Total phenolic content \\
& Reducing sugar \\
& PPO inactivation \\
& Sensory quality \\
\hline
\end{tabular}

\section{Color measurement}

The color measurements were performed using a digital colorimeter (CR-20 Konica Minolta, Tokyo, Japan) which shows the values as $L^{*}, a^{*}, b^{*}$. Total color change $(\Delta E)$ was obtained to know the difference in color of treated sample from control and was calculated by given equation.

$\Delta E=\sqrt{ }\left(L_{2}-L_{1}\right)^{2}+\left(a_{2}-a_{1}\right)^{2}+\left(b_{2}-b_{1}\right)^{2}$
Total soluble solids (TSS)

The TSS of the sugarcane juice was measured by refractometer which determines the total soluble solids and is expressed in degrees Brix.

\section{Titrable acidity}

Titrable acidity was calculated using sodium hydroxide as titrant. It is calculated by the formula:

\section{Titrable acidity $(\%)=\frac{\text { Equivalent } w \text { t. of acid } X \text { vol.of } N a O H \text { required } X 0.1}{10 X \text { wt.of sample taken }}$}

\section{Total Phenolic Content}

The total phenolic content was found by using FolinCiocalteu reagent method. In a testube $0.5 \mathrm{ml}$ of sample was taken and leveled up by addition of $7.5 \mathrm{ml}$ distilled water.
Thereafter $1 \mathrm{ml}$ of $50 \%$ Folin-Ciocalteu reagent was added and after $5 \mathrm{~min}, 1 \mathrm{ml}(20 \%)$ of $\mathrm{Na}_{2} \mathrm{CO}_{3}$ was added. The absorbance reading was taken after $45 \mathrm{~min}$ at room temperature at $720 \mathrm{~nm}$ using spectrophotometer.

Total phenolic content $(\mathrm{mg} G A E / 100 \mathrm{ml})=\frac{\text { Concentration of sample after absorbance reading }}{w \text { t. of sample taken } \times 10 \times 0.5}$

\section{Reducing Sugar}

The reducing sugar was determined by using DNS (3, 5dinitrosalicyclic acid) solution in which about $0.1 \mathrm{ml}$ of the sample of juice was equalized with $5.9 \mathrm{ml}$ of distilled water in testube. $3 \mathrm{ml}$ DNS was added in the sample and the test tubes were heated in boiling water for $5 \mathrm{~min}$. Then test tubes were taken out and while they were warm, $1 \mathrm{ml}$ of Rochelle salt 
solution was added in it. It was cooled and the absorbance reading was taken at $510 \mathrm{~nm}$.

$$
\text { Reducing sugar }(\%)=\frac{\text { Concentration } x 1}{50 \times \text { volume of sample taken }}
$$

\section{Polyphenol oxidase (PPO) activity}

PPO activity was calculated by using $0.2 \mathrm{M}$ catechol solution and $50 \mathrm{M}$ phosphate buffer ( $\mathrm{pH}$ 6.5). In a test tube, a mixture was prepared by addition of $4 \mathrm{ml}$ of phosphate buffer and 2 $\mathrm{ml}$ of catechol solution and $1 \mathrm{ml}$ of sugarcane juice was added. The absorbance reading was carried out at every $1 \mathrm{~min}$ interval at $420 \mathrm{~nm}$. One unit of PPO activity was defined as 0.001DA420/min (Ozoglu \& Bayindirli, 2002) ${ }^{\text {[7] }}$. Sample's activity was measured in terms of $\%$ residual PPO Activity (RA) as given in the equation.

\section{Unit of $\mathrm{ppo} / \mathrm{ml}=\left(\mathrm{Abs}_{\mathrm{f}}-\mathrm{Abs}_{\mathrm{i}}\right) / 0.001 *$ time}

\section{Microbial Load}

To determine the microbial load media was prepared by suspending $13 \mathrm{mg}$ of nutrient broth in $1000 \mathrm{ml}$ of water with $2 \%$ agar powder of the solution for bacteria test. Sterilized media was autoclaved at $121^{\circ} \mathrm{C}(15 \mathrm{lbs}$ pressure $)$ for 15 minutes. The media was the properly mixed before dispensing into the sterilized petriplates. The petriplates are kept in laminar air flow chambers for 20-25 min under the surveillance of UV light to solidify them. In sterile saline solution of $0.85 \mathrm{~g} / 100 \mathrm{ml}$, the pasteurized juice samples were diluted and were spread in petriplates. The plates were incubated at proper temperature and time i.e at $37^{\circ} \mathrm{C}$ for $24 \mathrm{~h}$ to obtain bacterial colonies. Thereafter the bacterial colonies were counted in which there were colonies between 30-300. Colonies formed per unit was calculated by formula:

$$
C F U / m l=\frac{\text { Number of colonies } x \text { dilution } \text { factor }}{\text { Volume of sample plated }}
$$

\section{Sensory Evaluation}

Sensory evaluation was done by 10 panelists through 9-point hedonic rating test method. The color, flavour, taste and overall acceptability were analyzed by the panelist of control and the treated samples.

\section{Statistical Analysis}

The statistical analysis was carried out to establish significant difference among the samples. All the experimental data was analyzed by analysis of variance (ANOVA) using MS EXCEL 2007 at 5\% $(P<0.05)$ significance level

\section{Result and Discussions}

The results are obtained of control and treated samples and quality parameters of fresh (control) sugarcane juice are tabulated in the below table:

Table 2: Quality parameters of Fresh sugarcane juice

\begin{tabular}{|c|c|}
\hline Quality parameters & Control sample \\
\hline Color parameters & $\mathrm{L}^{*}=24.3, \mathrm{a}^{*}=4.4, \mathrm{~b}^{*}=27.3$ \\
\hline $\mathrm{pH}$ & 5.5 \\
\hline Total soluble solids ( $\left.{ }^{\circ} \mathrm{Brix}\right)$ & $19.5 \pm 0.03$ \\
\hline Titrable acidity (\%) & $0.258 \pm 0.03$ \\
\hline Total phenolic content (mg of G.A.E /100ml) & $55.85 \pm 1.61$ \\
\hline Reducing sugar (\%) & $5.05 \pm 0.17$ \\
\hline PPO activity (unit of ppo /ml of juice) & $33.03 \pm 1.14$ \\
\hline Microbial load (log cfu/ml) & $7.31 \pm 1.08$ \\
\hline Sensory evaluation & $9 \pm 0$ \\
\hline
\end{tabular}

Sugarcane juice was further standardized to TSS of $14^{\circ}$ Brix by diluting the sugarcane juice and $\mathrm{pH}$ was adjusted to 4.6 by adding citric acid.

Most preservative attempts to prolong the shelf life of sugarcane juice have focused on pasteurization treatment by adjusting to a certain $\mathrm{pH}$ and TSS. (Bhupinder et al., 1991; Yusof et al., 2000) ${ }^{[10]}$. The effect of pasteurization treatment on quality parameters of sugarcane juice is shown in the table.

\begin{tabular}{|c|c|c|c|c|c|c|c|c|}
\hline $\begin{array}{c}\text { Treatment \& time } \\
\text { (sec.) }\end{array}$ & $\begin{array}{c}\text { Color change } \\
(\Delta \mathbf{E})\end{array}$ & $\begin{array}{c}\text { TSS } \\
\left({ }^{(} \text {brix }\right)\end{array} \mid$ & $\begin{array}{l}\text { Titrable } \\
\text { acidity } \\
(\%)\end{array}$ & $\begin{array}{c}\text { Total phenolic } \\
\text { (mg of G.A.E } \\
\text { /100ml) }\end{array}$ & $\begin{array}{c}\text { Reducing sugar } \\
(\%)\end{array}$ & $\begin{array}{c}\text { PPO } \\
\begin{array}{c}\text { (unit of ppo } / \mathrm{ml} \mathrm{of} \\
\text { juice) }\end{array} \\
\end{array}$ & $\begin{array}{c}\text { Microbial } \\
\text { load, } \\
\log (\mathbf{c f u} / \mathrm{ml})\end{array}$ & $\begin{array}{c}\text { Sensory } \\
\text { evaluation }\end{array}$ \\
\hline $80^{\circ} \mathrm{C}, 60 \mathrm{~s}$ & $18.36 \pm 0.2$ & $14 \pm 0$ & $0.21 \pm 0.07$ & $37.76 \pm 1.01$ & $3.99 \pm 0.08$ & $1.25 \pm 0.25$ & $4.9 \pm 0.18$ & $8.33 \pm 0.28$ \\
\hline $80^{\circ} \mathrm{C}, 90 \mathrm{~s}$ & $17.27 \pm 0.26$ & $14 \pm 0$ & $0.18 \pm 0.02$ & $33.84 \pm 0.34$ & $3.08 \pm 0.12$ & $1.25 \pm 0.66$ & $4.7 \pm 0.18$ & $8.33 \pm 0.28$ \\
\hline $80^{\circ} \mathrm{C}, 120 \mathrm{~s}$ & $15.31 \pm 0.4$ & $14 \pm 0$ & $0.16 \pm 0.05$ & $30.71 \pm 0.47$ & $3.05 \pm 0.22$ & $1.23 \pm 0.44$ & $4.6 \pm 0.3$ & $8.16 \pm 0.28$ \\
\hline $90^{\circ} \mathrm{C}, 60 \mathrm{~s}$ & $16.57 \pm 0.18$ & $14 \pm 0$ & $0.16 \pm 0.143$ & $27.80 \pm 0.71$ & $2.95 \pm 0.14$ & $1.08 \pm 0.38$ & $3.9 \pm 0.9$ & $8.16 \pm 0.28$ \\
\hline $90^{\circ} \mathrm{C}, 90 \mathrm{~s}$ & $15.6 \pm 0.19$ & $14 \pm 0$ & $0.14 \pm 0.002$ & $26.99 \pm 1.59$ & $2.54 \pm 0.11$ & $0.91 \pm 0.52$ & $3.5 \pm 0.18$ & $8.16 \pm 0.28$ \\
\hline $90^{\circ} \mathrm{C}, 120 \mathrm{~s}$ & $15.4 \pm 0.47$ & $14 \pm 0$ & $0.13 \pm 0.01$ & $22.76 \pm 1.11$ & $2.48 \pm 0.29$ & $0.88 \pm 0.53$ & $3.3 \pm 1.1$ & $8 \pm 0$ \\
\hline $100^{\circ} \mathrm{C}, 60 \mathrm{~s}$ & $14.3 \pm 0.03$ & $14 \pm 0$ & $0.13 \pm 0.02$ & $19.87 \pm 0.71$ & $2.14 \pm 0.13$ & $0.83 \pm 0.44$ & $2.9 \pm 1.2$ & $7.66 \pm 0.28$ \\
\hline $100^{\circ} \mathrm{C}, 90 \mathrm{~s}$ & $14.1 \pm 0.4$ & $14 \pm 0$ & $0.12 \pm 0.006$ & $17.42 \pm 1.59$ & $1.95 \pm 0.07$ & $0.60 \pm 0.09$ & $2.8 \pm 0.8$ & $7.16 \pm 0.28$ \\
\hline $100^{\circ} \mathrm{C}, 120 \mathrm{~s}$ & $13.7 \pm 0.36$ & $14 \pm 0$ & $0.11 \pm 0.01$ & $16.21 \pm 1.11$ & $1.70 \pm 0.14$ & $0.55 \pm 0.09$ & $2.7 \pm 0.9$ & $7 \pm 0$ \\
\hline $\mathrm{CD}(5 \%)$ & 2.5 & - & 0.036 & 2.85 & 0.38 & 0.31 & 4.07 & 0.25 \\
\hline
\end{tabular}

Table 3: Effect on quality parameters of sugarcane juice after pasteurization treatment

\section{Color measurement}

The color parameters $\mathrm{L}^{*} \mathrm{a}^{*}$ and $\mathrm{b}^{*}$ value changed with increase in temperature and time. All the values gradually increased as temperature increased with time. This might be due to the inactivation of enzymes at higher temperature which leads to increase in $\mathrm{L}^{*}$ value.

Sugarcane juice treated with $80^{\circ} \mathrm{C}$ for 60 s showed highest change in color i.e. $28.2 \pm 0.22$ and $100^{\circ} \mathrm{C}$ for 120 s showed lowest color change i.e. 18.64 \pm 0.33 . Therefore, at higher temperature and with longer holding time $\Delta \mathrm{E}$ value decreased.
Similar study was done by Azhari et al. (2018) ${ }^{[1]} . \Delta \mathrm{E}$ decreased significantly as temperature increased and but with effect of time, there was no significant difference observed.

\section{Total Soluble Solids}

There was no significant change in TSS for all the temperature and time combinations as earlier the TSS was adjusted to $14^{\circ}$ Brix. Huang et al. (2015) ${ }^{[3]}$ found similar findings where thermal pasteurization does not affect the TSS of sugarcane juice. 


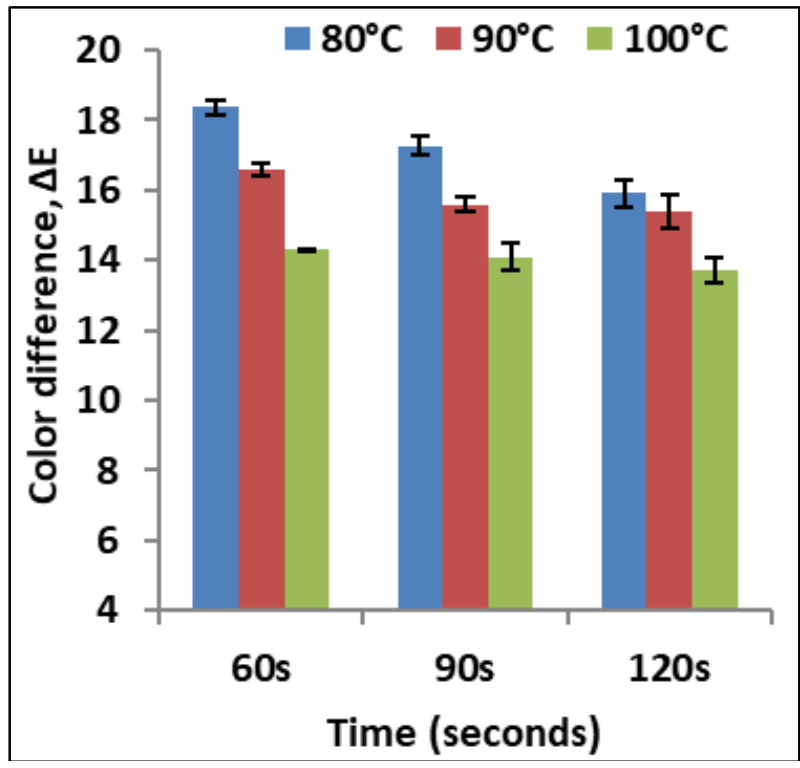

Fig 3: Effect of pasteurization treatment on color change

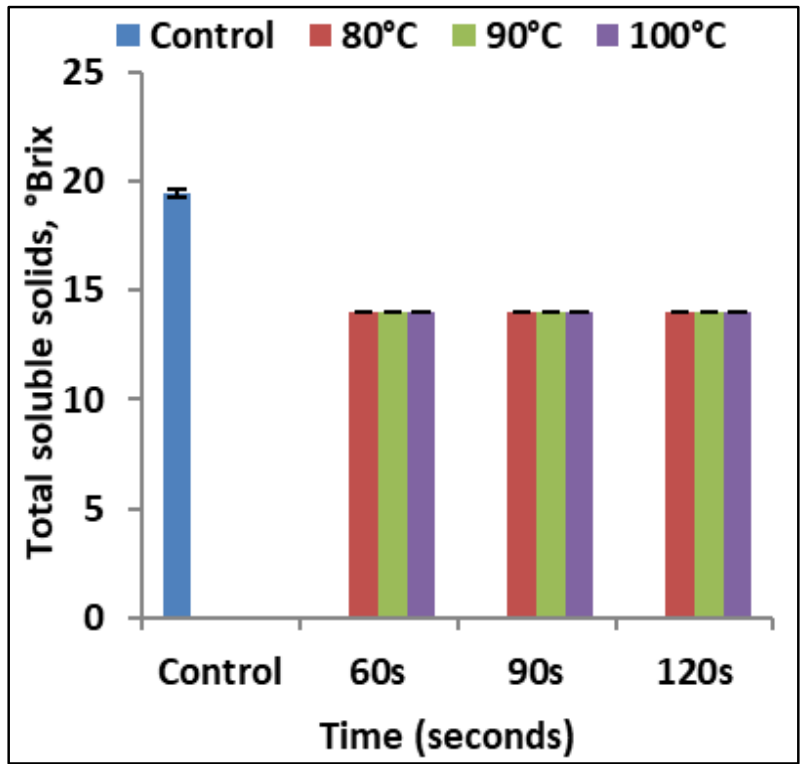

Fig 4: Effect of pasteurization treatment on TSS

\section{Titrable acidity}

The acidity of the samples decreased with increase in temperature and time. It was observed that decrease in acidity for higher temperature and for longer time was more which could be due to the inactivation of enzymes at higher temperature treatment.

Similar study was done by Huang et al. (2015) ${ }^{[3]}$ where acidity decreased but not significant due to thermal treatment. There was no significant difference in acidity. However, with effect of time, acidity decreased significantly. Therefore, time had significant effect on acidity but no significant effect of temperature was there.

\section{Total phenolic content}

The phenolic content decreased significantly with treatment. The highest value was observed for the sample treated with 80 ${ }^{\circ} \mathrm{C}$, for 60 s where it decreased to $32.39 \%$ whereas lowest value was observed at $100{ }^{\circ} \mathrm{C}$ for 120 s where it decreased to $70.97 \%$ with respect to control sample.

With both effect of temperature and time phenolic content decreased significantly.

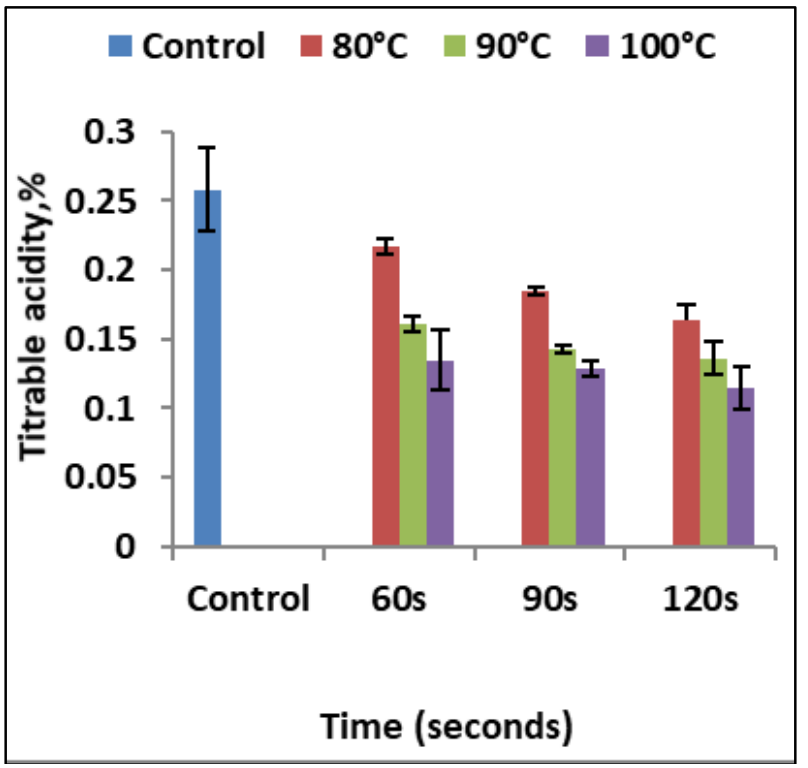

Fig 5: Effect of pasteurization treatment on titrable acidity

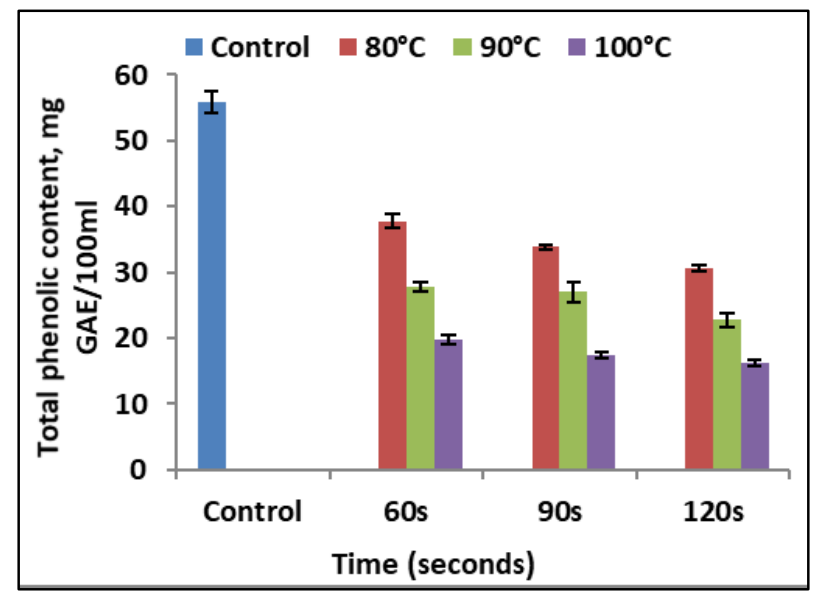

Fig 6: Effect of pasteurization treatment on total phenolic content

\section{Reducing Sugar}

Reducing sugar decreased to $21 \%$ at $80^{\circ} \mathrm{C}$ for 60 s which was higher than the sample treated with $100^{\circ} \mathrm{C}$ for $120 \mathrm{~s}$ which showed lowest reducing sugar i.e. decreased to $66.33 \%$ as compared to control sample. It was observed that at higher temperature for longer holding time reducing sugar decreases, as sucrose content in sugarcane juice changed due to the effect of pasteurization treatment. There was significant decrease in reducing sugar with increase in temperature. However, there was no significant decrease in reducing sugar when time increased with temperature. Similar study was done by Begum et al. (2015)

\section{PPO activity}

The main objective of the study is to prevent the browning of the sugarcane juice which is caused by the polyphenol oxidase enzyme. The PPO activity of control was about thirty folds higher than treated samples. The PPO activity decreased to $96.21 \%$ at $80^{\circ} \mathrm{C}$ for and at $100^{\circ} \mathrm{C}$ for $120 \mathrm{~s}$ it decreased to $98.33 \%$ with respect to control sample. PPO can be inactivated at high temperature thermal treatment. However, a slight degreening was observed at higher treatment temperature, which suggests there was chlorophyll degradation of sugarcanes at higher temperature which led to the degreening. There was significant decrease in PPO 
activity with increase in temperature, however with effect of time there was no significant decrease in PPO activity. Similar findings were made by Vamos-Vigyazo et al. (1981) [9], in which it was studied that PPO can be inactivated at high temperature thermal treatment

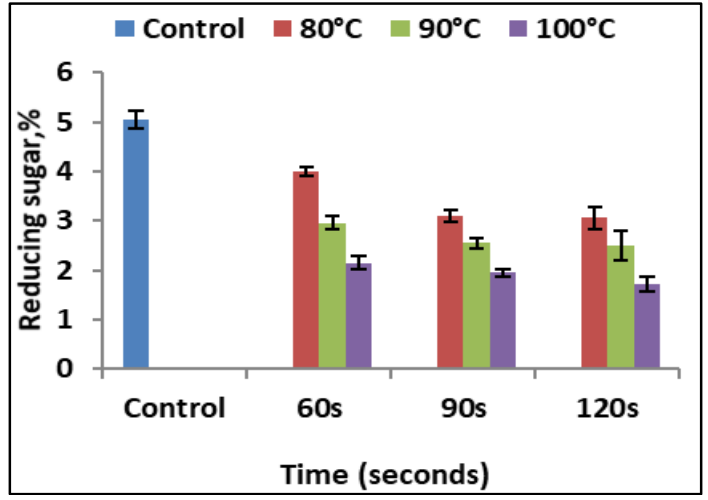

Fig 7: Effect of pasteurization treatment on reducing sugar

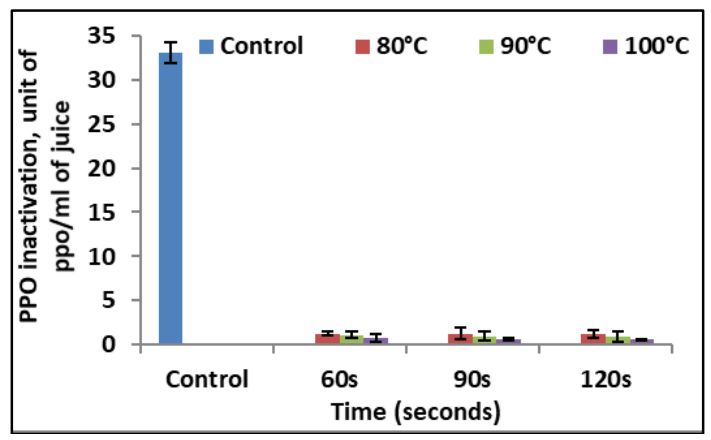

Fig 8: Effect of pasteurization treatment on PPO activity

\section{Microbial load}

The pasteurization treatment of sugarcane juice achieved a 3 $\log$ reduction in microbial count. Treatment at $80^{\circ} \mathrm{C}$ for $60 \mathrm{~s}$ led to decrease in microbial load to $33 \%$ and treatment at $100^{\circ} \mathrm{C}$ for 120 s led to $63 \%$ with respect to control sample. Similar results were obtained by Chauhan et al. (2002) ${ }^{[2]}$ on bacterial count of sugarcane juice. There was significant difference in microbial load with effect of temperature as well as with effect of time.

\section{Sensory evaluation}

There was significant decrease in sensory scores with effect of temperature but no significant decrease was seen with time. It was observed that as treatment temperature and time increased the sensory scores decreased. Similar findings were made by Kunitake et al. (2014) ${ }^{[6]}$.

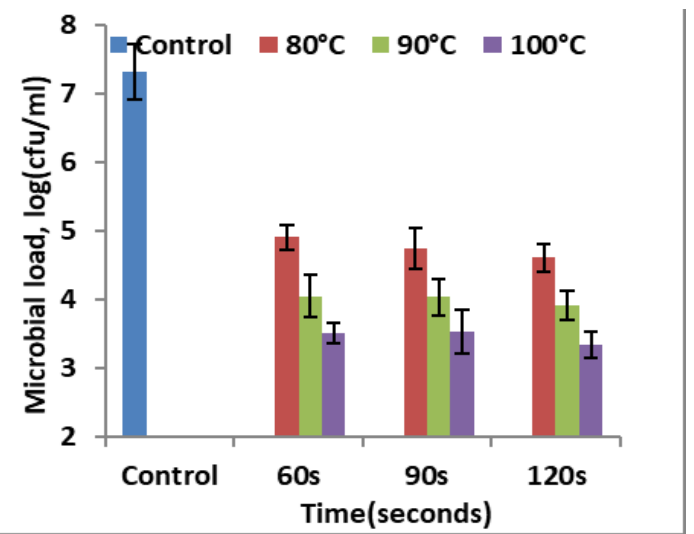

Fig 9: Effect of pasteurization treatment on microbial load

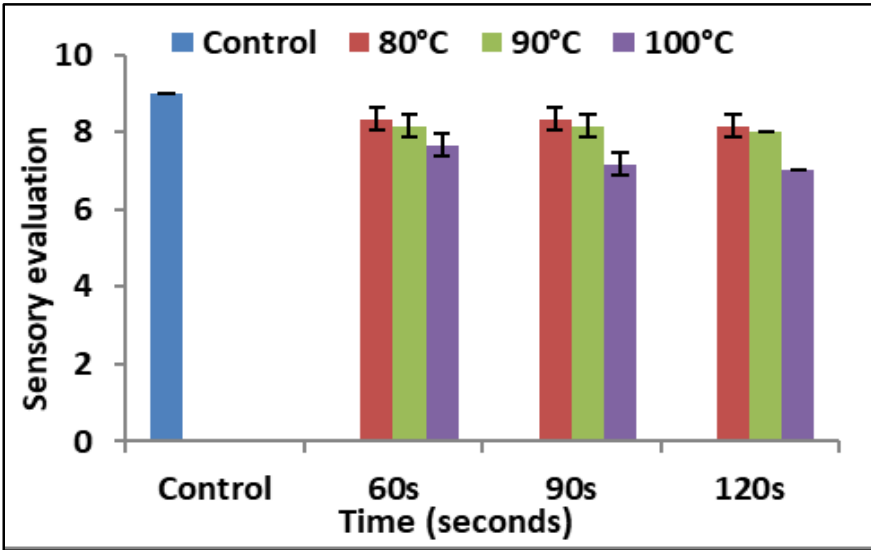

Fig 10: Effect of pasteurization treatment on sensory evaluation

\section{Optimization of Quality Parameters of Sugarcane Juice}

The optimization was done according to the changes in quality parameters after the treatment. The analysis was done to obtain the best desirable outputs i.e. minimum change in color, TSS, phenolic content and sensory evaluation and maximum decrease in reducing sugar, polyphenol oxidase activity and microbial load. The most desirable output obtained for color, TSS, titrable acidity, total phenolic content, reducing sugar, polyphenol oxidase activity, microbial load and sensory evaluation were as $15.6,14^{\circ} \mathrm{Brix}$, $0.143 \%, 27 \mathrm{mg}$ GAE$/ 100 \mathrm{ml}, 2.54 \%$, 0.91unit of $\mathrm{ppo} / \mathrm{ml}$ of juice, $3.5 \log \mathrm{cfu} / \mathrm{ml}$ and 8.66 respectively corresponding to the pasteurization treatment at $90^{\circ} \mathrm{C}$ for 90 seconds. In general, the combination was selected as it showed higher decrease in reducing sugar, PPO activity and higher sensory scores.

\section{Conclusion}

The pasteurization treatment after the standardization of juice used as hurdle in treatment of the cane juice. Therefore, treatment of sugarcane juice at $90^{\circ} \mathrm{C}$ for $90 \mathrm{sec}$ holding time was found to maintain the quality of juice with higher sensory scores, maximum decrease in PPO activity, reducing sugar and microbial load. Further the treated juice can be stored to increase the shelf life.

\section{References}

1. Azhari SH, Shahruddin R, Rahim MH. The effect of heat treatment and sonication on physiochemical and color attributes of yellow sugarcane, Malays. Appl. Biol 2018;47(5):129-134.

2. Chauhan OP, Singh D, Tyagi SM, Balyan DK. Studies on preservation of sugarcane juice, International Journal of Food Properties 2002;5(1):217-229.

3. Huang HW, Chang YH, Wang CY. High Pressure Pasteurization of Sugarcane Juice: Evaluation of Microbiological Shelf Life and Quality Evolution during Refrigeration Storage, Journals of food Bioprocess Technology 2015;8(12):2483-2494.

4. Kalpana K, Lal PR, Kusuma DL, Khanna GL. The Effects of Ingestion of Sugarcane Juice and Commercial Sports Drinks on Cycling Performance of Athletes in Comparison to Plain Water, Asian Journal of Sports Medicine 2013;4(3):181-189.

5. Kohinoor MB. Preservation of sugarcane juice using herbal clarificant, International Journal of Nutrition and Food Sciences 2015;4(5):530-534

6. Kunitake M, Ditchfield C, Silva C, Petrus R. Effect of pasteurization temperature on stability of an acidified 
sugarcane juice beverage, Journal of Food Processing and Technology 2014;5(12):554-561.

7. Ozoglu H, Bayindirli A. Inhibition of enzymic browning in cloudy apple juice with antibrowning agents, Food Control 2002;13(4):213-221.

8. Qudsieh HYM, Yusof S, Osman A, Rahman RA. Effect of maturity on chlorophyll, tannin, color, and polyphenol oxidase (PPO) activity of sugarcane juice (Saccharum officinarum Var. Yellow Cane), Journal of Agricultural and food Chemistry 2002;50(6):1615-1618.

9. Va'mos-Vigya' zo L, Haasd NF. Polyphenol oxidase and peroxidase in fruits and vegetables, Critical Reviews in Food Science and Nutrition 1981;15(1):49-127.

10. Yusof S, Shian LS, Osman A. Changes in quality of sugar-cane juice upon delayed extraction and storage, Food Chemistry 2000;68(4):395-401. 